\title{
Komite Audit, Profitabilitas, Solvabilitas, dan Ketepatan Waktu Pelaporan Keuangan Perusahaan Manufaktur-Sektor Logam
}

\author{
Bahtiar Effendi \\ Universitas Matana, Tangerang, Indonesia \\ bahtiar.effendi@matanauniversity.ac.id
}

\begin{abstract}
This study aims to determine the effect of audit committees, profitability, and solvability on the financial report punctuality of metal manufacturing companies listed in the Indonesia stock exchange. This study used quantitative approach. The data collection technique used in this study is document analysis in the form of financial statements of metal subsector manufacturing companies listed on the Stock Exchange for the 2014-2016 period accessed from www.idx.co.id. The sampling technique used was purposive sampling with a total sample of 30 companies. The data analysis method used was multiple linear regression analysis performed in SPSS 24.0 program. The results showed that (1) audit committees do not significantly affect the punctuality in submitting financial statements. (2) Profitability (ROA) has a negative effect or no significant effect on the financial reporting punctuality, (3) Solvability does not significantly influence the financial reporting punctuality (3).
\end{abstract}

Keywords: Audit Committees, Profitability, Solvability, punctuality.

\section{PENDAHULUAN}

Salah satu transparansi dan kualitas pelaporan keuangan adalah ketepatan waktu pelaporan keuangan. Informasi laporan keuangan harus disampaikan tepat waktu untuk menghindari hilangnya relevansi informasi yang terkandung didalamnya, sehingga keputusan ekonomi dapat segera diambil. Laporan keuangan yang disampaikan secara tepat waktu adalah laporan keuangan yang dapat memberikan manfaat bagi penggunanya terutama dalam hal pengambilan keputusan. Ketepatan waktu dalam penyampaian laporan keuangan sendiri telah diatur dalam Keputusan Ketua BAPEPAM dan LK Nomor KEP-346/BL/2011 tentang penyampaian Laporan Keuangan Berkala Emiten atau Perusahaan Publik. Dalam peraturan tersebut, laporan keuangan tahunan wajib disampaikan kepada BAPEPAM dan Lembaga Keuangan (LK), serta diumumkan kepada masyarakat paling lambat akhir bulan ketiga setelah tanggal laporan keuangan tahunan [1].

Beberapa variabel yang dapat mempengaruhi ketepatan waktu penyampaian laporan keuangan diantaranya ada tiga, yaitu komite audit, profitabilitas dan solvabilitas. Bapepam mengatur terkait keberadaan komite audit dan komisaris independen pada perusahaan publik di Indonesia yang ditandai dengan keluarnya Keputusan Direksi Bursa Efek Jakarta (BEI) [2]. Tugas Komite Audit adalah membantu Dewan Komisaris melakukan pemeriksaan yang dianggap perlu terhadap pelaksanaan fungsi direksi dalam kepengelolaan perusahaan. Menurut Purwati, komite audit bertugas memberikan pendapat professional yang independen kepada Dewan Komisaris terhadap laporan atau hal-hal yang disampaikan oleh Direksi [3].

Tugas dan tanggung jawab Komite Audit adalah memastikan prinsip- prinsip good corporate governance yang berkaitan dengan transparansi dan disclosure ditetapkan secara konsisten dan memadai. Permasalahan dalam pelaporan keuangan perusahaan publik dapat dilihat dari adanya sanksi dari BAPEPAM. Ketepatan waktu penyampaian laporan keuangan diatur dalam Undang-undang No. 8 tahun 1995 tentang pasar modal. Peraturan mengenai penyampaian laporan keuangan ini telah diperbaharui [4] dan mulai berlaku kembali pada tanggal 17 Januari 1996. Menurut Purwati, dalam peraturan tersebut disebutkan bahwa perusahaan wajib menyampaikan laporan keuangan tahunan yang telah diaudit selambat-lambatnya 120 hari sejak berakhirnya tahun buku.

Wiagustini menjelaskan bahwa profitabilitas menunjukkan kemampuan dari perusahaan dalam memperoleh laba atau ukuran efektivitas pengelolaan manajemen perusahaan [5]. Selanjutnya, menurut Hilmi dan Ali menjelaskan profitabilitas sebagai salah satu indikator keberhasilan perusahaan untuk menghasilkan laba, sehingga semakin tinggi 
profitabilitas, maka semakin tinggi pula kemampuan perusahaan untuk menghasilkan laba [6].

Wiagustini menjelaskan solvabilitas adalah kemampuan dari perusahaan untuk memenuhi kewajiban finansialnya baik dalam jangka pendek maupun jangka panjang, atau mengukur sejauh mana perusahaan dibiayai dengan hutang. Selanjutnya Effendi menjelaskan apabila tingkat solvabilitas perusahaan tinggi, maka resiko kegagalan perusahaan dalam mengembalikan pinjaman juga tinggi [7]. Solvabilitas memiliki pengaruh terhadap ketepatan waktu penyampaian laporan keuangan [8].

Perusahaan yang terlambat dalam penyampaian laporan keuangan secara tepat waktu akan dikenakan sanksi administrasi dan denda. Sanksi dan denda yang dikenakan cukup berat, namun demikian masih banyak perusahaan yang tidak dapat menyampaikan laporan keuangan dengan tepat waktu walaupun sudah dibentuk Komite Audit. Selama tahun 2002 BAPEPAM mengenakan sanksi administratif berupa denda kepada 186 emiten dan sanksi berupa peringatan tertulis kepada 4 emiten. Pada tahun 2003 sanksi administratif berupa denda diberikan kepada 83 emiten dan sanksi berupa peringatan tertulis kepada 1 emiten. Menurut Purwati, untuk tahun 2004 terdapat 27 emiten melakukan pelanggaran berupa tidak menyampaikan laporan keuangan secara tepat waktu.

Profitabilitas tidak berpengaruh terhadap ketepatan waktu penyampaian laporan keuangan [9]. Hilmi dan Ali menyimpulkan bahwa profitabilitas memiliki pengaruh terhadap ketepatan waktu penyampaian laporan keuangan. Sementara itu, solvabilitas tidak memiliki pengaruh terhadap ketepatan waktu penyampaian laporan keuangan [10].

Fakta telah menunjukkan banyak terjadi kasus keterlambatan penyampaian laporan keuangan oleh perusahaan yang go public di Indonesia. OJK mencatat ada sebanyak 33 kasus pelanggaran ditahun 2013. Pelanggaran tersebut mulai dari keterlambatan penyampaian laporan keuangan hingga transaksi efek di bursa (liputan6.com). Pada tahun 2013 BEI mencatat ada sekitar 54 emiten yang terlambat mengumpulkan laporan keuangan tahun 2011 yang telah diaudit untuk tahun 2012 (merdeka.com). Berdasarkan uraian tersebut dapat diketahui bahwa betapa pentingnya ketepatan waktu penyampaian laporan keuangan suatu perusahaan kepada para pemakai laporan keuangan. Akan tetapi masih banyak perusahaan yang tidak menyampaikan laporan keuangan perusahaannya dengan tepat waktu [11].
Rahmat, et.al. telah melakukan penelitian dengan topik yang serupa yaitu pengaruh komite audit [12]. Sedangkan Nasution telah melakukan penelitian dengan topik pengaruh likuiditas, ukuran perusahaan dan profitabilitas terhadap ketepatan waktu dalam pelaporan keuangan [13].

Perbedaan penelitian ini dengan penelitian terdahulu yaitu pada penelitian ini variabel yang diteliti adalah variabel komite audit, profitabilitas dan solvabilitas. Dari uraian tersebut para peneliti termotivasi untuk melakukan penelitian ini karena pertama, proses pelaporan keuangan akan termonitor dengan baik dengan keberadaan komite audit dalam perusahaan. Beberapa karakteristik yang dimiliki oleh komite audit sangat penting untuk memastikan apakah perusahaan telah menerapkan prinsip-prinsip akuntansi yang dapat menghasilkan sebuah laporan keuangan yang berkualitas. Kedua, menurut Nasution menyatakan profitabilitas merupakan suatu indikator keberhasilan perusahaan untuk dapat menghasilkan laba bagi perusahaannya juga sebagai pengukur efisiensi penggunaan modal. Selanjutnya yang Ketiga, solvabilitas merupakan informasi yang menunjukkan tingkat ketergantungan perusahaan terhadap utang untuk membiayai aset yang dimilikinya, dalam hal ini adalah resiko finansial yang akan dihadapi perusahaan dengan tingkat rasio solvabilitas yang tinggi karena kewajiban perusahaan yang tinggi atau resiko finansial yang rendah karena rasio solvabilitas perusahaan rendah [14], [15] .

Berdasarkan latar belakang masalah di atas, dapat disusun permasalahan sebagai berikut:

a. Apakah komite audit berpengaruh positif terhadap ketepatan waktu penyampaian laporan keuangan?;

b. Apakah profitabilitas berpengaruh positif terhadap ketepatan waktu penyampaian laporan keuangan?;

c. Apakah solvabilitas berpengaruh negatif terhadap ketepatan waktu penyampaian laporan keuangan?.

Berdasarkan permasalahan yang telah diuraikan di atas, maka tujuan penelitian ini adalah:

a. Untuk menganalisis pengaruh positif komite audit terhadap ketepatan waktu penyampaian laporan keuangan;

b. Untuk menganalisis pengaruh positif profitabilitas terhadap ketepatan waktu penyampaian laporan keuangan;

c. Untuk menganalisis pengaruh negatif solvabilitas terhadap ketepatan waktu penyampaian laporan keuangan. 


\section{KAJIAN PUSTAKA}

Teori Kepatuhan (Compliance Theory)

Teori kepatuhan telah diteliti pada ilmu-ilmu sosial khususnya di psikologis dan sosiologi yang lebih menekankan pada pentingnya proses sosialisasi dalam mempengaruhi perilaku kepatuhan seorang individu. Saleh dan Susilowati menyatakan bahwa seorang individu cenderung mematuhi hukum yang mereka anggap sesuai dan konsisten dengan normanorma internal mereka [16].Tuntutan akan kepatuhan terhadap ketepatan waktu dalam menyampaikan laporan keuangan perusahaan publik di Indonesia telah diatur dalam menyampaikan laporan keuangan perusahaan publik di Indonesia telah diatur dalam UU no. 8 tahun 1995 tentang pasar modal.

Pada tahun 1996, Bapepam juga mengeluarkan Lampiran keputusan Ketua Bapepam Nomor: 80/PM/1996 tentang kewajiban bagi setiap emiten dan perusahaan publik untuk menyampaikan laporan keuangan tahunan perusahaan dan laporan audit independennya kepada Bapepam selambatlambatnya pada akhir bulan keempat (120 hari) setelah tanggal laporan keuangan tahunan perusahaan. Kemudian diperketat dengan dikeluarkannya Kep17/PM/2002 yang telah melalui tahap pembaharuan peraturan [17] serta lampiran Keputusan Ketua yang menyatakan bahwa laporan keuangan tahunan harus disertai dengan laporan akuntan dengan pendapat yang lazim dan disampaikan kepada Bapepam selambat- lambatnya pada akhir bulan ketiga (90 hari) setelah tanggal laporan keuangan tahunan [18].

Teori kepatuhan dapat mendorong individu untuk lebih mematuhi peraturan yang berlaku, sama halnya dengan perusahaan yang berusaha untuk menyampaikan laporan keuangan secara tepat waktu. Karena selain merupakan kewajiban perusahaan untuk menyampaikan laporan keuangan tepat waktu, juga akan sangat bermanfaat bagi para pengguna laporan keuangan.

Ketepatan Waktu (timeliness)

Menurut Effendi, ketepatan waktu didefinisikan sebagai suatu pemanfaatan informasi oleh pengambil keputusan sebelum informasi tersebut kehilangan kemampuan untuk mengambil keputusan. Informasi dikatakan tidak relevan jika tidak tepat waktu. Ketepatan waktu tidak menjamin relevansi, akan tetapi relevansi tidak akan tercapai tanpa tepat waktu. Jadi informasi mengenai kondisi dan posisi perusahaan harus secara cepat dan tepat waktu sampai ke pemakai laporan keuangan [19].

Saleh dan Susilowati menyatakan bahwa tujuan pelaporan keuangan adalah menyediakan informasi yang menyangkut posisi keuangan suatu perusahaan yang bermanfaat bagi sejumlah besar pemakai dalam pengambilan keputusan ekonomi. Informasi yang relevan akan bermanfaat bagi para pemakai apabila tersedia tepat waktu sebelum pemakai kehilangan kesempatan atau kemampuan untuk mempengaruhi keputusan yang akan diambil. Ketepatan waktu menunjukkan rentang waktu antara penyajian informasi yang diinginkan dan frekuensi informasi pelaporan. Apabila informasi tersebut tidak disampaikan dengan tepat waktu akan menyebabkan informasi tersebut kehilangan nilai di dalam memengaruhi kualitas keputusan.

Hilmi dan Ali mendefinisikan ketepatan waktu dalam dua cara yaitu,

1. Ketepatan waktu didefinisikan sebagai keterlambatan waktu pelaporan dari tanggal laporan keuangan sampai tanggal melaporkan;

2. Ketepatan waktu ditentukan dengan ketepatan waktu pelaporan relatif atas tanggal pelaporan yang diharapkan.

Komite Audit

Sesuai dengan keputusan Bursa Efek Indonesia melalui Keputusan Bapepam menyatakan bahwa definisi komite audit adalah komite yang dibentuk oleh dewan komisaris perusahaan, yang anggotanya diangkat dan diberhentikan oleh dewan komisaris, yang bertugas membantu melakukan pemeriksaan atau penelitian yang dianggap perlu terhadap pelaksanaan fungsi direksi dalam pengelolaan perusahaan.

Keanggotaan Komite Audit dalam suatu perusahaan didefinisikan sebagai jumlah anggota komite audit. Di Indonesia, keanggotaan komite audit bermacam- macam, namun sebagai panduan, Bapepam mengatur bahwa anggota komite audit sekurang-kurangnya terdiri dari 3 (tiga).

Profitabilitas

Profitabilitas menunjukkan kemampuan perusahaan untuk menghasilkan laba pada masa mendatang dan laba merupakan informasi penting bagi investor sebagai pertimbangan dalam menanamkan modalnya [20]. Profitabilitas juga 
merupakan indikator dari keberhasilan operasi perusahaan [21].

Sekarwigati dan Effendi menjelaskan bahwa perusahaan yang memiliki profitabilitas tinggi dapat dikatakan bahwa laporan keuangan perusahaan tersebut mengandung berita baik dan perusahaan yang mengalami berita baik akan akan cenderuung menyerahkan laporan keuangan tepat waktu misalnya untuk peningkatan image perusahaan [22]. Menurut Hilmi dan Ali, hal ini juga berlaku jika profitabilitas perusahaan rendah, dimana hal ini mengandung berita buruk, sehingga perusahaan cenderung tidak tepat waktu menyerahkan laporan keuangannya.

Dalam penelitian ini perhitungan profitabilitas menggunakan ROA (Return On Asset),

dengan rumus sebagai berikut:

$$
R O A=\frac{\text { Laba Setelah Pajak }}{\text { Total Asset }} \chi 100 \%
$$

Solvabilitas

Wiagustini menjelaskan bahwa solvabilitas merupakan kemampuan dari perusahaan untuk memenuhi kewajiban finansialnya baik jangka pendek maupun jangka panjangnya, atau mengukur sejauh mana perusahaan dibiayai dengan hutang.

Solvabilitas merupakan kemampuan suatu perusahaan dalam memenuhi kewajiban jangka panjang. Solvabilitas digunakan untuk mengetahui sejauh mana utang perusahaan dapat ditutupi oleh asset yang dimiliki serta mengindikasikan tingkat kesehatan perusahan. Dalam penelitian ini perhitungan solvabilitas menggunakan DER (Debt to

$$
\text { DER }=\frac{\text { Total Debt }}{\text { Equity }} \times 100
$$

equity ratio), dengan rumus sebagai berikut:

Pengembangan Hipotesis

Pengaruh Komite Audit Terhadap Ketepatan Waktu Pelaporan Keuangan

Beberapa faktor seperti corporate governance, board independen, audit committees expertise, the role of auditor dan independensi auditor mampu meningkatkan kualitas pelaporan keuangan terhadap ketepatan waktu penyampaian laporan keuangan [23]. $\mathbf{H}_{1}$ : Komite Audit berpengaruh positif terhadap ketepatan waktu penyampaian laporan keuangan.

Pengaruh Profitabilitas Terhadap Ketepatan Waktu Pelaporan Keuangan

Devi dan Suaryana menyatakan bahwa semakin tinggi profitabilitas suatu perusahaan, maka perusahaan akan semakin cepat menyampaikan laporan keuangannya. Selanjutnya Sekarwigati dan Effendi menjelaskan bahwa perusahaan yang memiliki profitabilitas tinggi bisa dikatakan bahwa laporan keuangan perusahaan tersebut mengandung berita baik dan jika perusahaan yang mengalami berita baik akan menyerahkan laporan keuangannya sesegera mungkin atau tepat waktu misalnya untuk peningkatan image perusahaan. Perusahaan yang tergolong perusahaan besar tentu memastikan ketepatan pelaporan keuangan guna menunjukkan kinerja keuangan maupun presetasi yang dicapai oleh perusahaan yang lisitng di BEI [24].

$\mathbf{H}_{2}$ : Profitabilitas berpengaruh positif terhadap ketepatan waktu penyampaian laporan keuangan.

Pengaruh Solvabilitas Terhadap Ketepatan Waktu Pelaporan Keuangan

Menurut Devi dan Suaryana menyatakan bahwa solvabilitas yang rendah tidak menjamin perusahaan tersebut akan tepat waktu dalam penyampaian laporan keuangannya. Sebaliknya, solvabilitas yang tinggi tidak menjamin pula perusahaan tersebut akan terlambat dalam penyampaian laporan keuangan perusahaan tersebut. Perusahaan yang memiliki tingkat solvabilitas yang tinggi menandakan bahwa suatu perusahaan sangat bergantung pada hutang dari pihak luar untuk membiayai seluruh aktifitasnya. Hal ini menunjukkan bahwa perusahaan tersebut mempunyai risiko keuangan yang tinggi.

$\mathbf{H}_{3}$ : Solvabilitas berpengaruh negatif terhadap ketepatan waktu pelaporan keuangan.

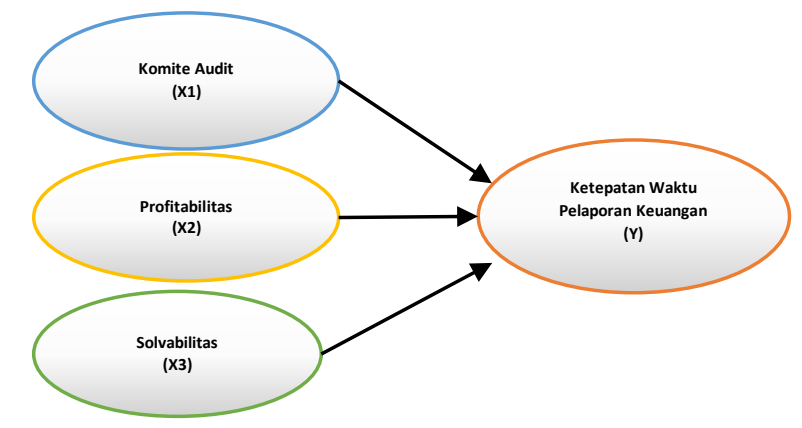

Gambar 1. Model Empiris

Gambar 1 di atas menjelaskan hubungan empiris antara komite audit, profitabilitas dan solvabilitas terhadap ketepatan waktu pelaporan keuangan.

\section{METODE PENELITIAN}

Populasi yang digunakan dalam penelitian ini adalah perusahaan logam yang terdaftar di Bursa Efek 
Indonesia (BEI) dan menerbitkan laporan keuangan tahunan (annual report) yang diaudit dan dipublikasikan di BEI untuk periode 2014, 2015, dan 2016 dengan jumlah perusahaan sebanyak 11 perusahaan logam manufaktur.

Berdasarkan teknik purposive sampling, diperoleh sampel sebanyak 10 perusahaan dengan total konten analisis sebanyak 30 pada tahun 20142016.

Uji hipotesis dilakukan dengan cara uji signifikansi (pengaruh nyata) variabel independen (X) terhadap variabel dependen (Y). Dalam penelitian ini digunakan analisis regresi linear berganda. Analisis regresi digunakan oleh peneliti apabila bermaksud meramalkan bagaimana keadaan (naik-turunnya) variabel dependen, dan apabila dua atau lebih variabel independen sebagai prediktor dimanipulasi atau dinaik turunkan nilainya. Untuk pengujian hipotesis yaitu dengan menggunakan analisis regresi berganda, berikut model regresi tersebut:

$$
\ln \left(\frac{T L}{1}-T L\right)=a+b 1 K K A+b 2 R O A+b 3 T D T A+e
$$

Keterangan Persamaan Regresi Berganda pada tabel 3.1 berikut ini:

Tabel 3.1 Penjelasan Persamaan Regresi Berganda

\begin{tabular}{|l|l|}
\hline Simbol & Keterangan \\
\hline $\ln (\mathrm{TL} / 1-\mathrm{TL})$ & $\begin{array}{l}\text { Dummy variable ketepatan waktu } \\
\text { pelaporan keuangan }\end{array}$ \\
$\mathrm{KKA}$ & Keanggotaan komite audit \\
$\mathrm{TL}$ & Timeliness \\
ROA & Return on Asset \\
TDTA & Total debt total equity \\
$b$ & koefisien regresi \\
$a$ & konstanta \\
$e$ & Error \\
\hline
\end{tabular}

\subsection{Menilai Kelayakan Model Regresi}

Analisis pertama yang dilakukan adalah menilai kelayakan model regresi logistik yang akan digunakan. Pengujian kelayakan model regresi logistik dilakukan dengan menggunakan goodness of fit test yang diukur dengan nilai Chi- Square pada bagian bawah uji Homser and Lemeshow. Perhatikan output dari Hosmer and lemeshow dengan hipotesis:

$H_{0}$ : Model yang dihipotesikan fit dengan data

$H_{a}$ : Model yang dihipotesikan tidak fit dengan data

Adapun dasar pengambilan keputusan: Perhatikan nilai goodness of fit test yang diukur dengan niali chi-square pada bagian bawah uji Hosmer and Lemeshow:

- Jika probabilitas $>0,05$ maka diterima

- Jika probabilitas <0,05 maka ditolak

\subsection{Penilaian keseluruhan model (overall model} fit)

Memperhatikan angka -2 log likelihood (LL) pada awal (block number $=0$ ) dan angka -2 log likelihood pada block number $=1$. Jika terjadi penurunan angka -2 log likelihood (block number 0 block number 1) menunjukan model regresi yang baik. Log likelihood pada regresi logistik mirip dengan pengertian "Sum of squared Error" pada model regresi, sehingga penurunan log likelihood menunjukkan model regresi yang baik.

\subsection{Menguji Koefisien Regresi}

Pengujian koefisien regresi dilakukan dengan memperhatikan beberapa hal berikut ini :

1. Tingkat signifikan $(\alpha)$ yang digunakan sebesar 5 persen $(0,05)$.

2. Kriteria penerimaan dan penolkan hipotesis didasarkan pada signifikan p-value (probabilitas value). Jika $p$-value $<\alpha$, maka hipotesis alternatif diterima.

\section{HASIL DAN PEMBAHASAN}

Hasil Analisis Statistik Deskriptif

Metode penentuan sampel pada penelitian ini adalah purposive sampling. Sampel yang terdapat pada penelitian ini berjumlah 10 Perusahaan sehingga jumlah sampel total pada 3 tahun penelitian (20142016) berjumlah 30 perusahaan.

Variabel yang digunakan pada penelitian ini adalah Ukuran Komite Audit, profitabilitas (ROA), dan solvabilitas (DER). Variabel-variabel ini merupakan varibel yang dapat mempengaruhi ketepatan waktu (timeliness) pelaporan keuangan. Pengujian variabel tersebut dapat diperoleh melalui hasil faktor-faktor apa sajakah yang berpengaruh terhadap ketepatan waktu (timeliness) pelaporan keuangan perusahaan-perusahaan manufaktur sektor logam di Indonesia.

Tabel 4.1 Distribusi Perusahaan yang Tepat

Waktu dan Tidak Tepat Waktu dalam Penyampaian Laporan Keuangan selama Periode Penelitian

\begin{tabular}{|c|c|c|c|c|c|c|}
\hline \multirow{3}{*}{$\begin{array}{c}\text { Kategori } \\
\text { Perusahaan }\end{array}$} & \multicolumn{6}{|c|}{ Tahun Penelitian } \\
\hline & \multicolumn{2}{|c|}{2014} & \multicolumn{2}{|c|}{2015} & \multicolumn{2}{|c|}{2016} \\
\hline & Jumlah & $\%$ & Jumlah & $\%$ & Jumlah & $\%$ \\
\hline $\begin{array}{l}\text { Pensahaan tepat } \\
\text { waktu }\end{array}$ & 10 & 100 & 6 & 60 & 0 & - \\
\hline $\begin{array}{l}\text { Perusahaan tidak } \\
\text { tepat waktu }\end{array}$ & 0 & - & 4 & 40 & 10 & 100 \\
\hline Total & 10 & 100 & 10 & 100 & 10 & 100 \\
\hline
\end{tabular}

Pengelompokan data sebagaimana tabel 4.1 menunjukan bahwa perusahaan sampel yang tidak 
tepat waktu dalam menyampaikan laporan keuangan mengalami peningkatan yaitu tahun 2014 sebanyak 0 (0\%) perusahaan, tahun 2015 sebanyak 4 (40\%) perusahaan dan tahun 2016 sebanyak 10 (100\%) perusahaan. Selanjutnya, untuk hasil statistik deskriptif sebagai berikut:

Tabel 4.2 Distribusi Perusahaan yang Tepat
Waktu dan Tidak Tepat Waktu dalam
Penyampaian Laporan Keuangan selama Periode
Penelitian
\begin{tabular}{|c|c|c|c|c|c|}
\hline & N & Minimum & Maximum & Mean & $\begin{array}{c}\text { Std. } \\
\text { Deviasion }\end{array}$ \\
\hline Profitabilitas & 30 & $-10,35$ & 10,00 & 0,4327 & 4,79863 \\
\hline Solvabilitas & 30 & 0,01 & 6,30 & 1,4060 & 1,70134 \\
\hline Komite Audit & 30 & 3 & 4 & 3,13 & 0,346 \\
\hline Timeliness & 30 & 0 & 1 & 0,53 & 0,507 \\
\hline $\begin{array}{c}\text { Valid N } \\
\text { (listwise) }\end{array}$ & 30 & & & & \\
\hline Sumber: Data sekunder yang diolah tahun $2014,2015,2016$ \\
\end{tabular}

Berdasarkan tabel 4.2 di atas menunjukan statistik deskriptif yang dimiliki perusahaanperusahaan yang dijadikan sampel dalam penelitian ini. Dari 30 sampel yang digunakan, variabel komite audit memiliki rata-rata anggota komite audit sebesar 3,13 dengan standar deviasi 0,346 dengan nilai maksimum adalah 4 dan minimum 3. Hal tersebut menunjukan bahwa sebagian besar perusahaan di Indonesia yang telah membentuk komite audit mempunyai jumlah anggota yang memenuhi persyaratan minimal 3 orang. Selanjutnya, variabel profitabilitas perusahaan menunjukan nilai rata- rata sebesar 0,4327\% dengan standar deviasi sebesar 4,79863\%. Rasio profitabilitas terendah dimiliki oleh PT Krakatau Steel Tbk pada tahun 2015 sebesar $10,35 \%$, sementara rasio tertinggi terjadi pada PT Citra Tubindo Tbk pada tahun 2014 sebesar 10\%. Kemudian, variabel solvabilitas, terdapat nilai minimum solvabilitas sebesar 0,01 yang dimiliki oleh PT. Jaya Pari Steel Tbk. pada tahun 2016, yang menandakan bahwa dari seluruh aset PT. Jaya Pari Steel Tbk. sebanyak $0,01 \%$ dibiayai oleh utang. Sedangkan nilai maksimum solvabilitas adalah sebesar 6.3 yang dimiliki oleh PT. Indal Alumunium Industri Tbk. pada tahun 2014, yang menandakan bahwa dari seluruh aset PT.Indal Alumunium Industri Tbk. sebanyak 6,3\% dibiayai oleh utang. Rata-rata variabel solvabilitas adalah sebesar 1,4060 dengan standar deviasi sebesar 1,70134 yang berarti bahwa dari seluruh asset yang dimiliki oleh seluruh perusahaan, rata-rata yang dibiayai oleh utang adalah sebanyak $1,4060 \%$.

Tabel 4.3 Uji Kelayakan Model Regresi Logistik

\begin{tabular}{|c|c|c|c|}
\hline \multicolumn{2}{|c|}{ Hasil Uji Keseluruhan Model } \\
\hline Iteration & -2 log likehood & Coefficients Constant \\
\hline Block 0 & 1 & 41,455 & 0,133 \\
\hline & 2 & 41,455 & 0,134 \\
\hline
\end{tabular}

\begin{tabular}{|l|c|c|c|c|c|c|}
\hline \multicolumn{2}{|c|}{ Iteration } & \multirow{2}{*}{$\begin{array}{c}-2 \text { Log } \\
\text { likehood }\end{array}$} & \multicolumn{4}{c|}{ Coefficients } \\
\cline { 4 - 7 } & & & & & & \\
\hline & & & & & \\
Block 1 & 1 & 41,293 & $-0,064$ & 0,023 & 0,065 & 0,031 \\
\hline & 2 & 41,293 & $-0,065$ & 0,024 & 0,065 & 0,031 \\
\hline & 3 & 41,293 & $-0,065$ & 0,024 & 0,065 & 0,031 \\
\hline
\end{tabular}

Berdasarkan Tabel 4.3 di atas, menunjukkan hasil uji kelayakan model regresi logistik, permasalahan dan hipotesis dalam penelitian ini akan dianalisis dengan logistic regresion. Langkah pertama yang dilakukan sebelum melakukan pengujian hipotesis adalah melakukan uji kelayakan dari model regresi logistik yang digunakan. Analisis ini didasarkan pada yang pertama Uji Keseluruhan Model (overall model fit). Dari hasil analisis overall model fit menunjukkan bahwa model analisis yang lebih baik. Hal ini diketahui adanya penurunan nilai 2Log Likelihood yaitu 41,455 pada block 0 menjadi 40,574 pada block 1 .

Uji Hosmer and Lemeshow. Untuk mengetahui perbedaan antara prediksi dan observasi dilakukan uji Hosmer and Lemeshow hasil dari pengujian kesamaan prediksi model regresi logistik dengan data observasi menunjukan bahwa nilai $\mathrm{Chi}_{-}$ square sebesar 0,883 dengan nilai signifikan sebesar 0,829 . Nilai signifikan tersebut lebih besar dari 0,05, maka tidak diperoleh adanya perbedaan antara prediksi model regresi logistik dengan data hasil observasi. Hal ini berarti bahwa model mampu diterima karena model sesuai dengan hasil observasinya.

Tabel 4.4 Kelayakan Model Regresi

\begin{tabular}{|l|l|l|l|l|}
\hline \multicolumn{2}{|l|}{} & Chi-square & df & Sig. \\
\hline Step 1 & Step & 0,163 & 3 & 0,983 \\
\hline & Block & 0,163 & 3 & 0,983 \\
\hline & Model & 0,163 & 3 & 0,983 \\
\hline
\end{tabular}

Sumber: Data sekunder yang diolah tahun 2014,2015,2016

Berdasarkan Tabel 4.4, dihasilkan hasil pengujian hipotesis secara simultan, dimana 
berdasarkan perhitungan spss dengan melihat hasil Omnibus Test of Model Coefficients menunjukkan bahwa nilai chi- square sebesar 0,163 dengan degree of freedom= 3 dan tingkat signifikansi sebesar 0.983. Nilai signifikansi tersebut lebih besar dari 0,05, maka Ha ditolak yang artinya bahwa variabel independen (komite audit, profitabilitas dan solvabilitas) secara bersama-sama tidak berpengaruh signifikan terhadap ketepatwaktuan (timeliness) penyampaian laporan keuangan.

Tabel 4.5 Kelayakan Model Regresi

\begin{tabular}{|c|c|c|c|c|c|c|c|c|c|}
\hline & & B & S.E. & Wald & df & Sig. & Exp(B) & Lower & Upper \\
\hline Step 1 & Profitabilitas & 0,024 & 0,090 & 0,069 & 1 & 0,793 & 1,024 & 0,858 & 1,222 \\
\hline & Solvabilitas & 0,066 & 0,223 & 0,087 & 1 & 0,768 & 1,068 & 0,689 & 1,654 \\
\hline & $\begin{array}{c}\text { Komite } \\
\text { Audit }\end{array}$ & 0,031 & 1,248 & 0,001 & 1 & 0,980 & 1,031 & 0,089 & 11,908 \\
\hline & Constant & $-0,065$ & 3,994 & 0,000 & 1 & 0,987 & 0,937 & & \\
\hline
\end{tabular}

Berdasarkan Tabel 4.5 di atas, diperoleh persamaan regresi logistik sebagai berikut:

$$
\mathrm{Y}=-0,065+0,031 \mathrm{X} 1+0,024 \mathrm{X} 2+0,066 \mathrm{X} 3+\varepsilon
$$

Dari persamaan regresi di atas dapat dijelaskan konstanta $=-0,065$ bertanda negatif artinya adanya pengaruh dari ke-empat rasio yaitu X1, X2, dan X3, maka perusahaan akan mengalami timeliness sebesar -0,065.

Variabel Variabel X1 (Komite Audit) dengan nilai 0,031 yang artinya setiap kenaikan sebesar 1 satuan ACSIZE, maka akan mempengaruhi timeliness sebesar 0,031. Variabel X2 (Profitabilitas) dengan nilai 0,024 yang artinya setiap kenaikan sebesar 1 satuan ROA, maka akan mempengaruhi timeliness sebesar 0,024. Variabel X3 (Solvabilitas) dengan nilai 0,066 yang artinya setiap kenaikan sebesar 1 satuan DER, maka akan mempengaruhi timeliness sebesar 0,066 .

Berdasarkan Uji Hipotesis dari perhitungan spss dari hasil Variable In the Equation diperoleh secara Parsial variabel X1 (ACSIZE) menunjukkan nilai signifikan 0,980 . Tingkat signifikan yang digunakan sebesar 0,05 berarti nilai $0,980>0,05$ ini mengidentifikasi bahwa Ha ditolak. Variabel X2 (ROA) menunjukkan nilai signifikan 0,793. Tingkat signifikan yang digunakan sebesar 0,05 berarti nilai $0,793>0,05$ ini mengidentifikasi bahwa Ha ditolak. variabel X3 (DER) menunjukkan nilai signifikan
0,768 . Tingkat signifikan yang digunakan sebesar 0,05 berarti nilai $0,768>0,05$ ini mengidentifikasi bahwa Ha ditolak. Hal ini menunjukan bahwa secara parsial ketiga variabel tersebut tidak mempengaruhi timeliness pelaporan keuangan perusahaan.

\section{KESIMPULAN DAN SARAN}

Berdasarkan tabel 4.5 yang menunjukan bahwa komite audit tidak mempengaruhi secara signifikan terhadap ketepatan waktu dalam menyampaikan laporan keuangan. Walaupun peran penting komite audit adalah mengawasi audit laporan keuangan dan memastikan apakah penyusunannya telah mengikuti prosedur dan pedoman yang berlaku serta menilai mengenai mutu pelayanan dan kewajaran biaya yang dibuat oleh auditor eksternal tetapi komite audit tidak mempengaruhi terhadap ketepatan waktu pelaporan keuangan.

Komite audit dibentuk oleh dewan komisaris perusahaan yang dalam fungsinya sebagai pengawas independen dalam perusahaan. Komite audit lebih menekankan terhadap aspek masyarakat yang berkaitan tentang pengelolaan mutu perusahaan, khususnya dalam penyusunan laporan keuangan sesuai dengan peraturan dari Bapepam, peran penting komite audit adalah untuk lebih memudahkan masyrakat dalam membaca informasi keuangan yang dipublikasikan perusahaan pada periode tertentu. Oleh karena itu komite audit tidak berpengaruh terhadap penyampaian laporan keuangan dikarenakan fungsi dari komite audit adalah sebagai pengawas independen pihak internal dan eksternal pada perusahaan atau sebagai perantara antara perusahaan dan masyrakat dalam pengelolaan aset perusahaan.

Profitabilitas (ROA) berpengaruh negatif atau tidak berpengaruh signifikan terhadap ketepatan waktu pelaporan keuangan perusahaan manufaktur sektor Logam periode 2014-2016. Hal ini dikarenakan perusahaan tidak mempertimbangkan tingkat profitabilitas yang dimiliki oleh perusahaan tersebut. Perusahaan yang profitabilitasnya tinggi atau rendah sama-sama ingin menyampaikan laporan keuangan tepat waktu tanpa melihat tingkat profitabilitas yang dimiliki perusahaan.

Solvabilitas tidak berpengaruh signifikan terhadap ketepatan waktu pelaporan keuangan. Hal ini terjadi dikarenakan tinggi atau rendahnya tingkat dari solvabilitas keuangan suatu perusahaan tidak mempengaruhi perusahaan untuk menyampaikan laporan keuangannya tepat waktu atau tidak tepat waktu. 


\section{REFERENSI}

[1] Devi, Ni Luh Lemi Sushmita., dan Suaryana, I Gusti Ngurah Agung. (2016). Pengaruh Profitabilitas dan Solvabilitas Terhadap Ketepatan Waktu dengan Reputasi Kantor Akuntan Publik Sebagai Pemoderasi. Bali: Universitas Udayana.

[2] Badan Pengawas Pasar Modal. (2000). Pembentukan Komite Audit, Surat Edaran Bapepam No. SE.03/PM/2000.

[3] Purwati, Atiek Sri. (2006). Pengaruh Karekteristik Komite Audit Terhadap Ketepatan Waktu Pelaporan Keuangan Pada Perusahaan Publik Yang Tercatat Di BEJ". Semarang: Universitas Diponegoro.

[4] Bapepam Nomor : 80/PM/1996. Tentang kewajiban bagi setiap emiten dan perusahaan publik untuk menyampaikan laporan keuangan tahunan.

[5] Wiagustini, Ni luh Putu. (2010). Dasar-Dasar Manajemen Keuangan. Denpasar. Udayana University Press.

[6] Hilmi, Utara dan Ali, Syaiful, 2008. "Analisis Faktor-faktor yang Mempengaruhi Ketepatan Waktu Penyampaian Laporan Keuangan (Studi Empiris pada Perusahaan-perusahaan yang Terdaftar di BEJ Periode 2004-2006), Jurnal Akuntansi Keuangan.

[7] Effendi, Bahtiar. (2019). Profitabilitas, Solvabilitas dan Audit Delay Pada Perusahaan Consumer Goods yang Terdaftar di BEI. Owner: Jurnal Riset dan Akuntansi, 2(2), 100108.

[8] Wirakusuma, Made Gede dan Putu Manik Cindrawati. (2011). Pengaruh Profitabilitas, Solvabilitas, Reputasi Auditor, Ukuran Perusahaan, Kandungan Laba, dan Jenis Industri pada Ketidaktepatan Waktu Publikasi Laporan Keuangan di PT. Bursa Efek Indonesia. Jurnal Ilmiah Akuntansi dan Bisnis. Vol. 6 No. 2.

[9] Iyoha, FO. (2012). Company Attributes and The Timeliness of Financial Reporting in Nigeria. Business Intelligence Journal.

[10] Dewi, Karina Mutiara dan Pamudji, Sugeng. (2013). "Analisis Faktor-faktor Yang Mempengaruhi Ketetapan Waktu dan Audit delay Penyampaian Laporan Keuangan" (Diponegoro Journal of Accounting Volume 2, Nomor 2, Tahun 2013).
[11] Purbasari, Mirani. (2014). Analisis Pengaruh Karakteristik Komite Audit Dan Profitabilitas Terhadap Timeliness Laporan Keuangan. Semarang: Universitas Diponegoro.

[12] Rahmat, M. M., Takiah, M. I., dan N. M, Saleh. (2008). Audit Committee Characteristics in Financially Distressed and Non Financially Distressed Company. Managerial Auditing Journal. 24(7): 123-133.

[13] Nasution, Khiyanda Alfian. (2013). "Pengaruh likuiditas, ukuran perusahaan dan profitabilitas terhadap ketepatan waktu dalam pelaporan keuangan. (Studi Empiris Pada Perusahaan Manufaktur Yang Terdaftar Di BEI Periode 2009-2011)". Padang. Universitas Padang.

[14] Aprilia, Rosella \& Effendi, Bahtiar. (2019). Pengaruh Pergantian Manajemen, Kepemilikan Publik dan Financial Distress terhadap Auditor Switching. STATERA: Jurnal Akuntansi dan Keuangan, 1(1), 61-75.

[15] Effendi, Bahtiar. (2019). Kualitas Audit, Kondisi Keuangan, Ukuran Perusahaan dan Penerimaan Opini Audit Going Concern. Owner: Jurnal Riset dan Akuntansi, 3(1), 9-15.

[16] Saleh, Rachmad dan Susilowati. (2004). "Studi Empiris Ketepatan Waktu Pelaporan Keuangan Perusahaan Manufaktur di Bursa Efek Jakarta". Jurnal Bisnis Strategi. Vol.13. h. 67-80.

[17] Peraturan Bapepam Nomor X.K.2. Tentang laporan keuangan tahunan.

[18] Peraturan Bapepam Nomor : Kep-36/PM/2003 yang menyatakan bahwa laporan keuangan tahunan harus disertai dengan laporan keuangan akuntan dengan pendapat lazim dan disampaikan kepada Bapepam selambatlambatnya pada akhir bulan ketiga (90 hari) setelah tanggal laporan keuangan tahunan.

[19] Wijayanti, Ngestiana. (2009). Pengaruh Profitabilitas, Umur Perusahaan, Ukuran Perusahaan, Dan Kepemilikan Publik Terhadap Ketepatan Waktu Pelaporan Keuangan Perusahaan. Surakarta: Universitas Sebelas Maret.

[20] Nurmiati. (2016). Faktor-Faktor Yang Mempengaruhi Ketepatan Waktu Pelaporan Keuangan. Samarinda: Universitas Mulawarman.

[21] Effendi, Bahtiar \& Khamdevi, Muhammar. (2017). Tingkat Efisiensi Energi Bangunan Hijau dan Profitabilitas Manufaktur. MARKA (Media Arsitektur dan Kota): Jurnal Ilmiah Penelitian, 1(1), 19-24. 
[22] Sekarwigati, Mega \& Effendi, Bahtiar. (2019). Pengaruh Ukuran Perusahaan, Profitabilitas, dan Likuiditas terhadap Corporate Social Responsibility Disclosure. STATERA: Jurnal Akuntansi dan Keuangan, 1(1), 16-33.

[23] Nuraini, Nani., E. Bahtiar., \& S. Iwan. (2018). Corporate Governance dan Environmental Disclosure. Jurnal Ilmiah Akuntansi dan Pariwisata, 1(2), 19-30.
[24] Susiyanti, Susiyanti \& Effendi, Bahtiar. (2019). Struktur Modal, Ukuran Perusahaan, Likuiditas dan Profitabilitas Perusahaan Manufaktur yang Listing di BEI. Owner: Jurnal Riset dan Akuntansi, 3(2), 66-72. 